\title{
Assessment of Spatial Pattern And Distribution Of Major Crops in Assam, India
}

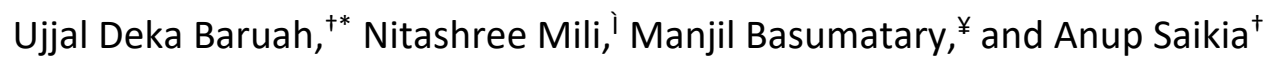

\begin{abstract}
Various indicators such as production, yield, mechanisation of farms, workforce engaged in farming are generally used for the evaluation of the status of the agricultural sector in a region. Of these, the cropping pattern is one such indicator that signifies how developed the farming system of a region is. To assess the cropping pattern, a number of statistical indices are available-cropping intensity, crop combination, crop concentration, and crop diversification. This research seeks to evaluate the cropping pattern in Assam, India and examines the status of its agricultural sector. It was found that the cropping intensity increased at a gradual rate of $3 \%$ per decade. A total of nine statistical indices were used to estimate crop diversification. These indices were compared amongst themselves to determine the most optimal method for the study area. It was found that the ogive and entropy methods were best suited to Assam in an evaluation of its crop diversification. Further, these crop diversification values were ranked and thereafter, a composite score (Kendall's method) was derived. The composite score indicated that much of western and northern Assam had a high degree of crop diversification.
\end{abstract}

Keywords: Cropping Pattern; Crop Diversification; Ogive and Entropy Method; Assam; India

\footnotetext{
${ }^{+}$Department of Geography, Gauhati University,Guwahati-781014,India

${ }^{*}$ Corresponding Author, Email: udbmail@gauhati.ac.in

'Department of Geography, Cotton University,Guwahati-781001, India

¥Department of Geography, Gossaingaon College, Gossaingaon, India

(C) 2020 Deka Baruah et al. This is an Open Access article distributed under the terms of the Creative Commons Attribution License (http://creativecommons.org/licenses/by/2.0), which permits unrestricted use, distribution, and reproduction in any medium, provided the original work is properly cited.
} 


\section{Introduction}

Agro-climate resources are significantly affected by rapid warming, altered cropping intensities as well as cropland patterns (Zhang et al., 2013). Thus, cropping intensity is an essential parameter in the assessment of the cropping pattern of a region (Boserup, 1965; Caviglia \& Andrade, 2010; Novelli et al., 2017). Crop combination provides a sound basis for agricultural regionalisation (Bhatia, 1965). Crops generally tend to be grown in combinations and it was rare that a particular crop occupied a position of total isolation from other crops in a given areal unit at a given point of time (Hussain, 2001). The regionalisation of a state on the basis of a single crop was significant since an aerial unit could have a diverse range of crops that were grown in varied combinations (Bhatia, 1965)). Often a region could be demarcated based on a single crop, for instance, the division of India into rice, wheat, mustard regions. However, the agricultural significance was not well explained in such delineation schemes and often tended to suppress areal crop diversities. Thus, for an understanding of the actual characteristics of an agro-climatic region, crop combinations play a significant role (Hussain, 2001).

Two widely used indices in agricultural geography are crop concentration and crop diversification. Both help to assess the cropping pattern of a region in a detailed manner (Roy \& Barman, 2014). Crop concentration refers to the spatial density of an individual crop or the variation in the density of crops in a region over a specific span of time. On the other hand, crop diversification refers to the species diversification of cultivated crops by farmers considering their likely risks and returns leading to a production portfolio that minimises risk and increases income (De, 2003; De \& Kamal, 2014; Hazra, 2001; Roy \& Barman, 2014). The regional dominance of a crop has some relationship with the other crops grown in the area and has a strong bearing on the degree of crop specialisation or diversification prevailing therein. Generally the more significant the dominance of some crop in an areal unit, the lesser are the crop diversification and vice versa (Bhatia, 1965). Crop diversification additionally refers to "the diversification of varieties and ecotypes of the similar variety" (FAO, 2001) to maximise the output of primary products as well as value-added processed products to enable farmers to enhance their incomes (Bradshaw et al., 2004; Mengxiao, 2001). While diversification is frequently advocated as an effective tool for managing a variety of farm business risks, the precise form of diversification advocated was often unclear. The practice of increasing the number of crops cultivated also indicates crop diversification, which may be due to farm-level responses to climatic variability and change (Bradshaw et al., 2004).

The demarcation of crop concentration regions helps in ascertaining the areas where a particular crop grows well even with minimal inputs, and thus play an essential role in agricultural development and planning (Raju, 2012; Roy \& Barman, 2014). The approach used in this study involves the utilisation of a variety of measures of crop diversification which indicates the extent of dispersion and concentration of activities in a given time and space by a single quantitative indicator (Pal \& Kar, 2012). Assam being an agrarian state, more than $50 \%$ workforce is engaged in agricultural activities (Baruah, 2018). Farmers whose agricultural fields are ravaged by constant floods, practise diversified cropping patterns (Mandal et al., 2013). The farmers tended to combine different crops as a riskaversion strategy to sustain crop losses accruing as a result of recurrent floods (Mandal, 2010). Although there exist farm-level studies in terms of cropping pattern (Mandal, 2014), these have been uni-directional in nature. Our study emphasised a multi-directional approach to address agricultural development through cropping pattern. The diversified cropping pattern has enabled farmers to boost farm income. This analysis intended to regionalise Assam on the basis of crop combinations. The region was demarcated on the basis of its ten major crops for the crop combination and spatial 
concentration of each crop. Additionally, agricultural development was assessed in terms of crop diversification. This helps identify the areas with single crop concentration, thereby laying a foundation for decision makers to focus on specific low crop diversification areas.

The research is organised as follows: it begins with a brief description of the study area. Following this, we discuss the methodology deployed here for this research. The results of this research are critically discussed in the sections following methodology.

\section{The Study}

From an agricultural perspective, Assam is the most well-endowed state in northeast India (Figure 1) bestowed as it is by the fertile alluvial Brahmaputra and Barak plains. It is bounded by the lofty Eastern Himalaya of Arunachal Pradesh in the North and Meghalaya plateau, Mizoram and Tripura hills in the South. The region's climate is generally humid-wet tropical with rainfall mostly due to South-East Monsoon during June-September (Duncan et al., 2016). Over $86 \%$ of the farms in Assam are of small and marginal size $(>2 \mathrm{Ha})$, and the operational holding per capita amounts to a mere 1.11 ha only (Baruah, 2018).

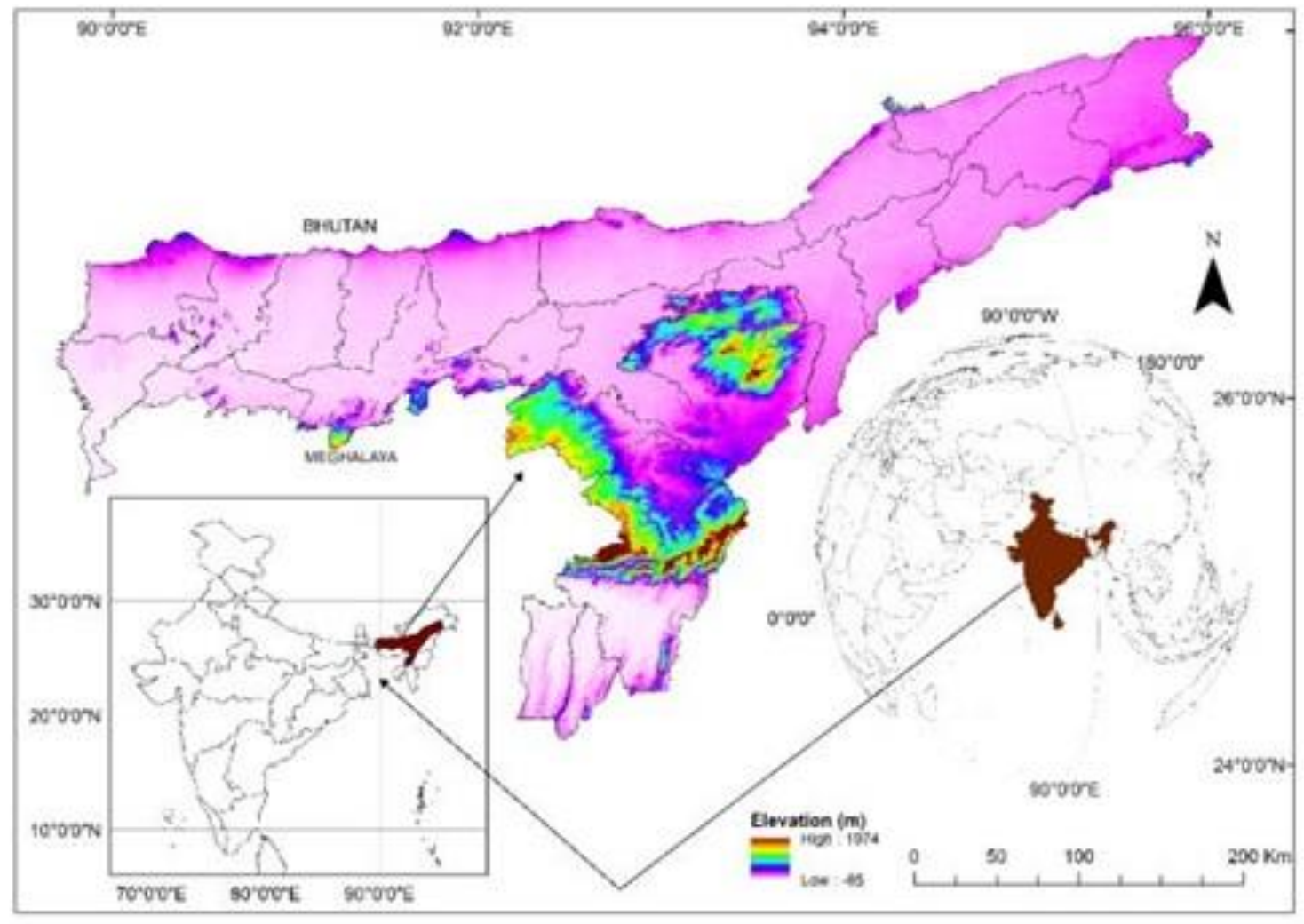

Figure 1: Location Map of Assam, India Source: Authors

\section{Database and Methodology}

The top ten crops in terms of acreage are considered for the assessment of cropping pattern in Assam during 2003-2012 (DES, 2015): winter paddy (loacally known as Sali), autumn paddy (Ahu), summer paddy (Boro), rape \& mustard, potato, wheat, jute, black lentil
(Matikalai), sugarcane, lentil pulse (Masur). The statistical data of crops were collected from the Directorate of Economics and Statistics, Government of Assam and the Reserve Bank of India. ${ }^{1}$ These crops occupy about $96 \%$ of the gross cropped area. Other than these crops

\footnotetext{
${ }^{1}$ Retrieved on 01 May 2019 from, www.indiastat.com
} 
there are many other crops which are grown in small quantities less than $1 \%$.

\section{Cropping Intensity}

The cropping intensity was assessed using the following formula (Ahlawat \& Renu, 2016):

$$
\text { Cropping Intensity }=\left(\frac{\text { Gross Cropped Area }}{\text { Net Sown Area }}\right) \times 100
$$

\section{Crop Combination}

\section{Weaver's Method}

The crop combination estimate was assessed based on a modified Weaver (1954b) statistical technique averaged for the period 2003-2012. Weaver's method takes into account the crops whose minimum shares were above $1 \%$ but without any upper limits. This modified analysis was based on acreage statistics and involved crops with shares of more than $1 \%$ (lower limit) but less than 65\% (upper limit) of the gross cropped area. The share of $65 \%$ was taken as a threshold to remove the effect of single crop dominance in terms of acreage and to include the maximum number of crops. Crops with more than $65 \%$ act as an outlier which suppresses the effect of other crops with smaller acreage shares. Crop combinations not derived due to the area $(<1 \%$ and $>65 \%)$ of particular crop effects the Weaver variance. District wise variations were studied to delineate the agricultural regions of Assam.

$$
d=\sum d 2 / n, \text { where, }
$$

d was the difference between the actual crop percentage in the region and the appropriate percentages in the theoretical curve and $n$ was the number of crops in a given combination. Therefore, the lowest deviation of the actual percentages from the theoretical percentages would establish the identity and the number of crops in the basic combination for a district (Hussain, 2001; Weaver, 1954b). However, Weaver's technique gives rather unwieldy combinations for the units of high crop diversification (Hussain, 2001).
The deviation of the real percentage of crops was calculated for all possible combinations in the component areal units against a theoretical standard. The theoretical curve for the standard measurement was applied as follows:

Monoculture $=100 \%$ of the total gross cropped area in one crop

2-crop combination $=50 \%$ in each of two crops.

3 -crop combination $=33.3 \%$ in each of three crops.

4-crop combination $=25 \%$ in each of four crops

5 -crop combination $=20 \%$ in each of five crops

10-crop combination $=10 \%$ in each of 10 crops

Therefore, as per Weaver's crop combination:

\section{Crop Concentration}

\section{Location Quotient}

Crop concentration was derived using the Location Quotient method (Bhatia, 1965; De \& Kamal, 2014). The use of this technique seems to lead to a better understanding of the crop patterns than was possible with the usual ratio and isopleth methods that have been in use for about three decades (Bhatia, 1965; Jones, 1930; Sharma, 2008; Smith, 1949; Weaver, 1954a). The crop concentration index is as follows:

$$
\text { Crop Concentration Index }=\frac{C_{i j} / C_{j}}{C_{i} / C}
$$

Where,

$\mathrm{C}_{\mathrm{ij}}$ - Area of crop $\mathrm{x}$ in a component areal unit 
Cj- Area of all crops in the component areal

Ci- Area of crop $\mathrm{x}$ in the entire state

C- Area of all crops in the entire state

\section{Crop Diversification}

It was a measure to identify a region's variation in the number of crops per acreage (hectares, sq $\mathrm{Km})$. We used nine different methods to assess the crop diversification in Assam. All nine methods were correlated to evaluate their actual patterns. The values derived from these methods were finally used to detect the spatial crop diversification and concentration based on a composite score of Kendall ranking method.

$$
\text { Herfindahl Index }=\sum_{1=1}^{N} P_{i}{ }^{2}
$$

Where,

$\mathrm{P}_{\mathrm{i}}=$ area proportion of the $\mathrm{i}^{\text {th }}$ crop in total cropped area.

$\mathrm{N}=$ the total number of crops

\section{Transformed HI (THI)}

The Herfindahl Index is a measure of concentration (Pal \& Kar, 2012). Therefore, it was modified as:

$$
\mathrm{THI}=1-\mathrm{HI}
$$

Alternatively,

$$
\mathrm{THI}=1-\sum_{1=1}^{n} P_{i}{ }^{2}
$$

\section{Ogive Index (OI)}

It measures the deviation from an equal distribution (Attaran \& Zwick, 1987; Tress, 1938) of crops. The ogive index has been extensively

$$
O I=N \sum_{i=1}^{N}\left(P_{i}-1 / N\right)^{2}
$$

$\mathrm{P}_{\mathrm{i}}=$ area proportion of the $\mathrm{i}^{\mathrm{th}}$ crop in the total cropped area.

$\mathrm{N}=$ the total number of crops

$1 / \mathrm{N}$ is assumed to be the "ideal" share of crops in the total cropped area.

\section{Gibbs-Martin's Index (GMI)}

Gibbs-Martin's Index has been used for delineating crop diversification (Das \& Mili, 2012; Ranjana, 2012; Roy \& Barman, 2014). The Gibbs-Matin's index was given by Gibbs et al. (1962) as:

$$
G M I=1-\frac{\sum X^{2}}{\left(\sum X\right)^{2}}
$$

Where,

used for assessing the diversity of various sectors (De \& Kamal, 2014; Pal \& Kar, 2012; Palan, 2010; Samen, 2010; Saraswat et al., 2014; Sharma, 2008; Wasylenko et al., 1978). Ogive index is expressed as: 
$x=$ Percentage of the total cropped area under an individual crop

\section{Jasbir Singh's Method (JSM)}

Singh (1976) put forward a modified form of Bhatia (1965), where the number of crops considered, was limited to areas with not less than $5 \%$ in comparison to Bhatia's limit of $10 \%$ to the total cropped area.

$$
\mathrm{JSM}=\frac{\text { Percentage of the total cropped area under ' } \mathrm{n} \text { ' crops }}{\text { Total number of crops ' } \mathrm{n} \text { ' }}
$$

\section{Gini's Coefficient (GC)}

Gini's Coefficient of 1912 has been widely used in assessing diversity of various inequalities; later it was introduced in the assessment of crop

$$
G C=\sum_{i=1}^{N} P_{i}{ }^{2}
$$

$\mathrm{P}_{\mathrm{i}}=$ area proportion of the $\mathrm{i}^{\mathrm{ith}}$ crop in total cropped area.

\section{Entropy Index (EI)}

Entropy Index or Shannon Entropy Index is as an inverse measure of concentration possessing logarithmic character and has been widely used for identification of concentration and diversification of various sectoral elements (Attaran \& Zwick, 1987; Gebreyesus, 2016; Hart, 1971; Sharma, 2008; Tabner, 2007). It is given by:

$$
\begin{gathered}
E I=-\sum_{i=1}^{N} P_{i} * \ln P_{i} \\
E I=\sum_{i=1}^{N} P_{i} * \ln \left(1 / P_{i}\right)
\end{gathered}
$$

Where,

$\mathrm{P}_{\mathrm{i}}=$ area proportion of the $\mathrm{i}^{\text {th }}$ crop in the total cropped area.

$\mathrm{N}=$ the total number of crops

\section{Hart Entropy Index (HEI)}

This entropy index can be used to determine regions of high and low crop diversification and concentration (Pal \& Kar, 2012)

$$
\begin{gathered}
H E I(P i)=-\sum_{i=1}^{N} P_{i} * \log P_{i}, 0 \leq H E I(P i) \leq \log N \\
\log N_{e}=\sum_{i=1}^{N} P_{i} * \log \left(\frac{1}{P_{i}}\right)=H E I(P i)
\end{gathered}
$$

Complete equality occurred when $\mathrm{Pi}=1 / \mathrm{N}$ for all $\mathrm{I}$ and $\mathrm{Pi}=\log \mathrm{N}$

\section{Composite Entropy Index (CEI)}

This index possesses all desirable properties of the Modified Entropy Index and has been used to compare diversification across situations having a different and large number of crops since it gives due weightage to the number of crops (Pal \& Kar, 2012). It is expressed as: 


$$
C E I=-\left[\sum_{i=1}^{N} P_{i} * \log _{N} P_{i}\right] X\left\{1-\left(\frac{1}{N}\right)\right\}
$$

Where,

$\mathrm{P}_{\mathrm{i}}=$ area proportion of the $\mathrm{i}^{\text {th }}$ crop in total cropped area.

$\mathrm{N}=$ the total number of crops

\section{Kendall's ranking coefficient}

The ranks of each of the areal components were averaged (Kendall, 1939). The ranks of districts which had equal yields were allotted by splitting in the usual way, that is, if the $r$ th, $(r+1)$ th. . . $r+$ $s)$ th districts had equal yields, each was allotted a rank $\{r+(r+1)+\ldots+(r+s) /(s+1)$ and the next district would rank as $(r+s+1)$.

The results are discussed in the following sections.

\section{Results and Discussions}

The ratio of net sown area to gross cropped areawas calculated at $67.34 \%$ during the year 2011-12, which amounted to 2.8 million hectares net sown area out of 4.2 million hectares gross cropped area. The net sown area increased at the rate of 3.7 ('000 ha per annum), which was statistically significant at 0.01 significant level ( $p$ value $=0.010$ ) (Figure $2 a$ ). At this rate, it was expected that the net sown area would be 2869 (' $000 \mathrm{Ha}$ ) in 2030 . The trend of the gross cropped area was increasing at the rate of
10,200 ha/ annum, which was statistically significant at the 0.05 significance level ( $p$-value $=0.016$ ) (Figure $2 b$ ). Thus, it can be estimated that the expected gross cropped area in Assam in 2030 would be 4265.4 ('000 Ha). The cropping intensity in Assam exhibited an increasing trend. The intensity of cropping increased at a nominal rate of $0.3 \%$ per annum during 1984-2012 that was statistically significant ( $p$ value $=0.0032$ ) at 0.01 level (Figure $2 c$ ). The cropping intensity was expected to be 152.16 by 2030 at current rates. The cropping intensity in Assam (Figure 2d) was highest in Dhemaji, Lakhimpur Kokrajhar, Baksa, and Nalbari and the lowest being in the districts of Tinsukia, Dibrugarh, Sibsagar, Jorhat, Kamrup (rural) \&Kamrup (metro), Nagaon, Cachar, and Karimganj. Moderate cropping intensities existed in Goalpara, Dhubri, Bongaigaon, Chirang, Barpeta, Darrang, Udalguri, Sonitpur, Morigaon, Karbi Anglong, Dima Hasao, Hailakandi and Golaghat districts. The cropping intensity index value was as low as 110.06 (Sibsagar) and as high as 202.89 (Lakhimpur).
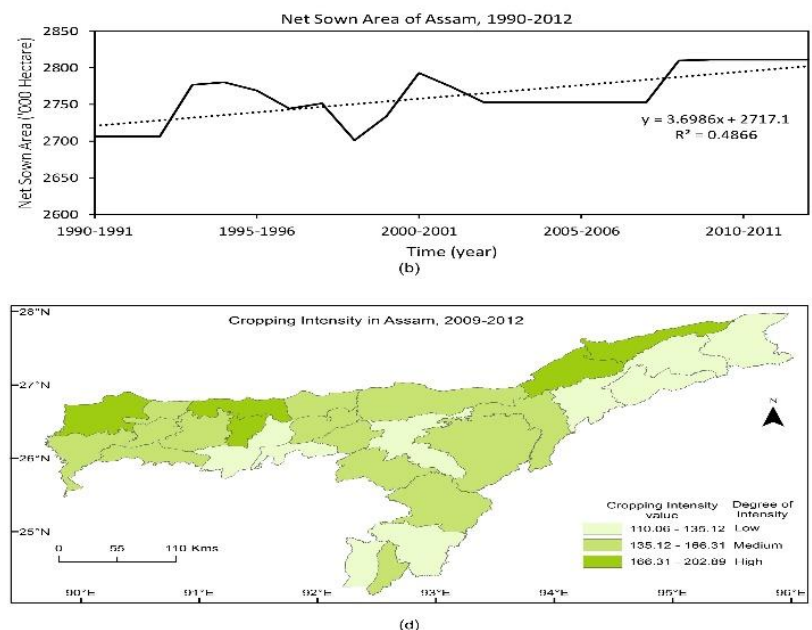

Figure 2: Trend of (a) Gross cropped area of Assam; 1990-2012 ; (b) net sown area of Assam, 1990-2012;(c) Cropping intensity in Assam, 1984-2012; (d) District wise cropping intensity in Assam, 2009-2012

Source: Authors 


\section{Pattern of Crop Combination}

Assam is home to a variety of crops, but the contribution of these crops varied substantially. The region was mostly paddy dominated with $82 \%$ share out of ten major crops (Table 1 ). While winter paddy dominated with $58 \%$, autumn paddy $13 \%$, summer paddy $11 \%$ and the rest of the crops amounted to $18 \%$ of the total. The proportion of rape and mustard, the $2^{\text {nd }}$ largest crop in terms of acreage after paddy amounted to $8 \%$ to the total crop acreage (Table 1).

\begin{tabular}{|l|l|l|l|}
\hline \multicolumn{2}{|l|}{ Table 1: Composition of Major Crops in Assam During 2003-2012 } \\
Rank & Name of Crop & $\begin{array}{l}\text { Average Area } \\
\text { (Ha) }\end{array}$ & Average Area (\%) \\
\hline 1 & Winter Paddy & 1741186 & 58 \\
\hline 2 & Autumn Paddy & 394901 & 13 \\
\hline 3 & Summer Paddy & 314694 & 11 \\
\hline 4 & Rape \& Mustard & 239978 & 8 \\
\hline 5 & Potato & 81276 & 3 \\
\hline 6 & Wheat & 62828 & 2 \\
\hline 7 & Jute & 54682 & 2 \\
\hline 8 & Matikalai & 38873 & 1 \\
\hline 9 & Sugarcane & 26804 & 1 \\
\hline 10 & Masur & 22682 & 1 \\
\hline Source: Authors & & & \\
\hline
\end{tabular}

The cropping pattern of Assam shows discrete crop combination regions. The modified Weaver methods gave a seven crop combination region in Assam due to the exclusion of crops higher than $65 \%$. Some crops (winter/ autumn paddy) of a few districts have shown more than $65 \%$ share to the gross cropped area. Therefore, these crops (winter/ autumn paddy) were excluded from the calculation of crop combination for those districts of Assam. The spatial pattern of cropping pattern and agricultural regions based on crop combination (3a). There was no monoculture being practised and 6-7 crop combinations were absent in the region (Table 2). The districts had as high as 10 and as low as 2 crop combinations, without any moderate crop combinations.

The deviation of crop combination in the year 2003-04 and 2011-12 from the normal 20032012 (the base year for Chirang, Baksa, Udalguri, and Kamrup (metro) was during 2005-2012. It was observed that in 2003-04, the districts of central and western Assam had fewer crop combinations than normal, while districts of eastern Assam (except Dibrugarh and Dhemaji) had higher crop combinations. A few districts showed no change in crop combination viz. Lakhimpur, Karbi Anglong, Sibsagar, Cachar, and Chirang (Figure 4b). Most of the districts (eastern and southern Assam) had higher or no change in crop combination than the normal during 201112 (Figure 4c). The crop combination region of the latter period indicates that the multicropping rather than mono-cropping has gained prominence in the region. The maximum acreage of crops was under a ten crop combination in CBVZ with $1,70,634$ hectare (42\%) of gross cropped area 4,07,951 hectare in Assam (Table 3). The Weaver's method gave ten cropcombination-(WP/SP/AP/RM/J/W/S/P/M/Ma) in the Central Brahmaputra valley zone which includes the Nagaon and Morigaon districts. Five crop combination of Upper Brahmaputra Valley Zone shared the least amount of net cropped area 14,228 hectare (3\%) to gross cropped area. The least crop combination was the hill zones which comprise of Karbi Anglong and Dima Hasao (erstwhile NC Hills) districts during 20032012. The crop combination was calculated with the exception of winter paddy in some agroclimatic zones due to its very high share (>65\%) to the gross cropped area. It was observed that the winter paddy contribution to the total paddy 
was highest amongst autumn, summer and winter paddy during 2003-2012 (Table 4).
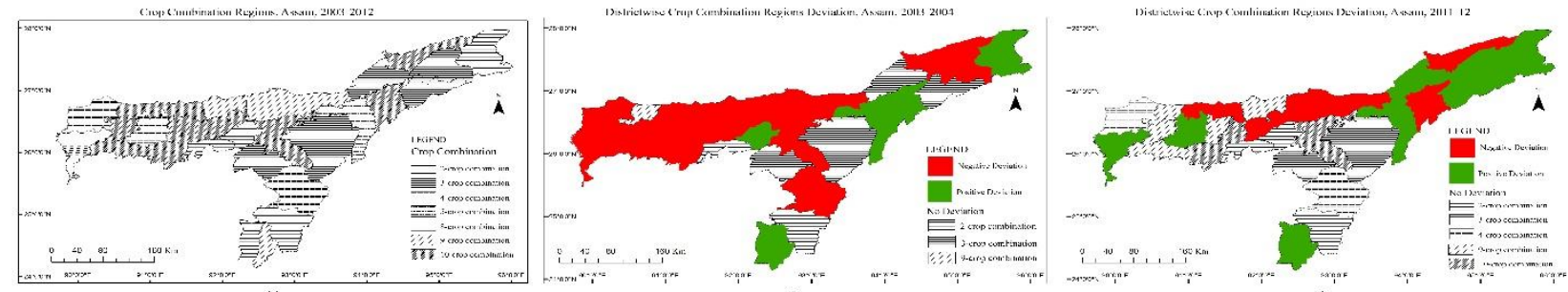

3 a) Crop Combination Regions of Assam (2003-2012) based on Weaver's Method; 3 (b) and (c) District wise Crop Combination Regions Deviation, Assam, 2003-04 and 2011-12 respectively. Source: Authors

Table 2: Crop Combination of Assam 2003-2012 based on Weaver's Method

\begin{tabular}{|c|c|c|}
\hline No. of Crops & $\begin{array}{l}\text { No. of } \\
\text { Districts }\end{array}$ & Names of Districts \\
\hline Monoculture & - & - \\
\hline 2 & 5 & Tinsukia, Kamrup ( M ), Morigaon,Cachar, Karimganj \\
\hline 3 & 4 & Sibsagar, Dibrugarh, Karbi Anglong, Lakhimpur \\
\hline 4 & 4 & Jorhat, Kokrajhar, Barpeta, Dima Hasao \\
\hline 5 & 1 & Golaghat, \\
\hline 6 & - & - \\
\hline 7 & - & - \\
\hline 8 & 1 & Dhubri \\
\hline 9 & 3 & Hailakandi, Sonitpur, Udalguri \\
\hline 10 & 9 & $\begin{array}{l}\text { Bongaigaon,Chirang,Goalpara, Kamrup ( R ), Nalbari, Baksa, Nagaon, } \\
\text { Darrang, Dhemaji }\end{array}$ \\
\hline
\end{tabular}

Source: Authors

Table 3: Crop-Combination Order and Coverage in Assam, 2003-2012

\begin{tabular}{|c|c|c|c|c|}
\hline $\begin{array}{l}\text { Agro- } \\
\text { Climatic } \\
\text { Zones }\end{array}$ & Crops Combination & $\begin{array}{c}\text { No. of } \\
\text { Districts }\end{array}$ & $\begin{array}{l}\text { Gross cropped area } \\
\qquad(\mathrm{Ha})\end{array}$ & $\begin{array}{c}\text { Gross cropped area } \\
(\%)\end{array}$ \\
\hline UBVZ & $\mathrm{RM} / \mathrm{AP} / \mathrm{P} / \mathrm{SP} / \mathrm{M} / \mathrm{S}$ & 5 & 14,228 & 3 \\
\hline LBPZ & $\begin{array}{l}\text { WP/SP/AP/RM/J/W/P/M } \\
/ \mathrm{Ma}\end{array}$ & 10 & $1,17,335$ & 29 \\
\hline CBVZ & $\begin{array}{l}\text { WP/SP/AP/RM/J/W/S/P/ } \\
\mathrm{M} / \mathrm{Ma}\end{array}$ & 2 & $1,70,634$ & 42 \\
\hline BVZ & $\mathrm{AP} / \mathrm{SP}$ & 3 & 15,391 & 4 \\
\hline $\mathrm{HZ}$ & $\mathrm{RM} / \mathrm{AP} / \mathrm{S}$ & 2 & 27,171 & 7 \\
\hline NBPZ & $\mathrm{AP} / \mathrm{RM} / \mathrm{SP} / \mathrm{P}$ & 5 & 63,191 & 15 \\
\hline Assam & AP/SP/RM & 2 & $4,07,95$ & 100 \\
\hline
\end{tabular}


Table 4: Area Under Rice in Assam, 2010-15

\begin{tabular}{l|lllll|}
\hline \multicolumn{5}{|c|}{ Area Under Rice ('000 Hectares) } \\
\hline Season & $2010-11$ & $2011-12$ & $2012-13$ & $2013-14$ & $2014-15$ \\
\hline Autumn & 313 & 277 & 238 & 222 & 196 \\
\hline Winter & 1859 & 1876 & 1857 & 1828 & 1883 \\
\hline Kharif Total & 2172 & 2152 & 2096 & 2050 & 2079 \\
\hline Summer/ Rabi & 399 & 385 & 393 & 399 & 416 \\
\hline Total & 2570 & 2537 & 2488 & 2449 & 2495 \\
\hline Source: Authors & & & & &
\end{tabular}

\section{Pattern of Crop Concentration and Diversification}

\section{Crop Concentration}

\section{Paddy}

Winter rice (Sali) cultivation became the dominant cropping practice amongst the Ahoms. However, it was confined to Upper Assam. Autumn (Ahu) and flood-resistant summer (Boro) paddy cultivation continued to be prevalent in Lower Assam (Guha, 1966; Sinha, 2001). The pattern of distribution of autumn paddy was highly concentrated in the western part of Assam (Kokarajhar, Chirang, Bongaigaon, Barpeta, Udalguri). These districts showed a low concentration of autumn paddy while the hill districts of Assam showed moderate concentration. The concentration of summer paddy was very high in the districts of Dhubri and Morigaon. Apart from these districts, Nagaon, erstwhile Kamrup, Nalbari, Barpeta, Goalpara showed a high concentration of summer paddy. Western Assam -. Dibrugarh, Tinsukia, Sibsagar, Golaghat, Jorhat, Dhemaji, Karbi Anglong, Dima Hasao showed a very low or insignificant concentration of summer paddy. Winter paddy showed a contrasting difference between summer and autumn paddy. The concentration of winter paddy was just the opposite of summer and winter paddy concentration. Eastern Assam showed a very high concentration of winter rice in the districts of Karbi Anglong, Cachar, Karimganj, Hailakandi, Sibsagar, Dhemaji, Baksa and Nalbari.

\section{Rape and Mustard}

Rape and mustard concentration was very high in Dhemaji, Lakhimpur, Chirang and Kokrajhar and low in Dibrugarh, Sibsagar, Goalpara, Cachar, Karimganj and Hailakandi. In general, the districts of eastern Assam had a high concentration of rape and mustard - Dhubri, Bongaigaon, Barpeta, Baksa along with Karbi Anglong, Golaghat, Morigaon and Sonitpur.

Jute

Dhubri had the highest concentration of jute, followed by Nagaon, Morigaon and Baksa. Some districts had insignificant or no jute concentration - Kamrup (rural), Chirang, Baksa, Nalbari, Lakhimpur, Dhemaji, Tinsukia, Dibrugarh, Sibsagar, Jorhat, Golaghat, Cachar, Hailakandi, and Karimganj. Moderate concentration was observed in Goalpara, Barpeta, Bongaigaon, Udalguri, Darrang, Karbi Anglong and Sonitpur. More than climatic considerations, this state of affairs could be due to cultural and traditions of following specific crops amongst the populace of certain districts with immigrant population from the neighbouring country of Bangladesh.

\section{Wheat}

The highest concentration of wheat was observed in Dhubri, Bongaigaon, Barpeta, Morigaon followed by high concentration in Kokrajhar, Chirang, Goalpara, Kamrup (rural), Baksa, Udalguri, Sonitpur and Nagaon. Insignificant or low crop concentration was observed in Tinsukia, Sibsagar, Dibrugarh, Jorhat, Dima Hasao, Cachar, Hailakandi, and Karimganj. 


\section{Potato}

The potato was highly concentrated in Dhemaji, Udalguri and Dima Hasao followed by Lakhimpur, Darrang, Sonitpur, Baksa, and Barpeta. The lowest concentration of potato occurred in Dibrugarh, Sibsagar, Karbi Anglong and Morigaon. Moderate concentration occurred in Kokrajhar, Dhubri, Chirang, Bongaigaon, Nalbari, Kamrup (R), Nagaon, Karimganj, and Tinsukia.

\section{Matikalai}

Chirang, Baksa, and Barpeta had the highest concentration of Matikalai (black lentil) followed by Goalpara, Bongaigaon, Nalbari, Kamrup (R), Darrang, and Dhubri. The lowest concentration was found in Tinsukia, Dibrugarh, Sibsagar, Jorhat, Karbi Anglong, Dima Hasao, Cachar, Hailakandi, Cachar, Karimganj. This crop was moderately concentrated in Nagaon, Lakhimpur, Sonitpur, Udalguri, Morigain, Kamrup (M) and Kokrajhar.

\section{Masur}

The highest concentration of Masur (red lentil pulse) was found in Goalpara, Bongaigaon, Dhubri and Jorhat followed by Kokrajhar, Barpeta, Baksa, Udalguri, and Darrang. Moderate concentration was observed in Tinsukia, Dhemaji, Lakhimpur, Sonitpur, Nagaon, Dima Hasao and Chirang, while the districts Karimganj, Sibsagar, and Dibrugarh had the lowest concentration.

\section{Sugarcane}

Sugarcane concentration was very high in Dima Hasao followed by Karbi Anglong and Nagaon. Moderate concentration of sugarcane was seen in Jorhat, Golaghat, Sonitpur, Morigaon, Darrang, Kamrup (R), Baksa, Udalguri, Karimganj, and Hailakandi. The lowest crop concentration was found in Tinsukia, Dibrugarh, Sibsagar, Dhemaji, Lakhimpur, Goalpara, Dhubri, Kokrajhar, Chirang, Bongaigaon, Barpeta, Nalbari, Kamrup (M) and Cachar.

The ranking maps, based upon a comparison of the relative strength of different crops within each component areal unit, bring out the general patterns of crop dominance (Bhatia, 1965). The districts of western Assam including Darrang and Sonitpur, had a higher degree of concentration of crops than districts of eastern Assam during 2003-12. The overall crop dominance was found to be in the western Assam and in the north bank of the Brahmaputra river (Figure 4b).

\section{Crop Diversification}

All the crop diversification indices (Figure 5a) showed similar results, with the highest diversity of crops beings observed in most districts of eastern Assam and Dima Hasao district (erstwhile NC Hills). The correlation amongst the indices of crop diversification was found to be significantly high, enabling a precise demarcation of the crop regions (Table 4).

In the case of Bhatia and Singh's method, CV is not widely accepted in contemporary times because here there are no definite upper or lower threshold limits (Pal \& Kar, 2012). Amongst the other methods, Gini's Coefficient and entropy indices are good measures given their better scale of resolution. Herfindahl's Index has been a widely used measure of crop diversification but given the output scale of resolution, Gini's Coefficient and entropy measures are considered superior. Entropy index, Ogive index, and Modified entropy index are more relatively more effective ( $P a l$ \& Kar, 2012).

The composite ranking (Kendall, 1939) of crop diversification index (Figure $5 \mathrm{~b}$ ) indicates similar results, with the highest diversity of crops observed in parts of eastern Assam (Dhubri, Bongaigaon, Barpeta, Darrang) and Dima Hasao (erstwhile NC Hills). Moderately high crop diversification was found in Kokrajhar, Chirang, Goalpara, Kamrup, Udalguri. Medium crop diversification occurred in Sonitpur, Nagaon and Morigaon. Lakhimpur, Dhemaji, Tinsukia, Kamrup (M), Baksa, Karbi Anglong, and Nalbari districts had low crop diversification. The lowest crop diversification occurred in Dibrugarh, Sibsagar, Jorhat, Golaghat, Cachar, Karimganj and Hailakandi. 

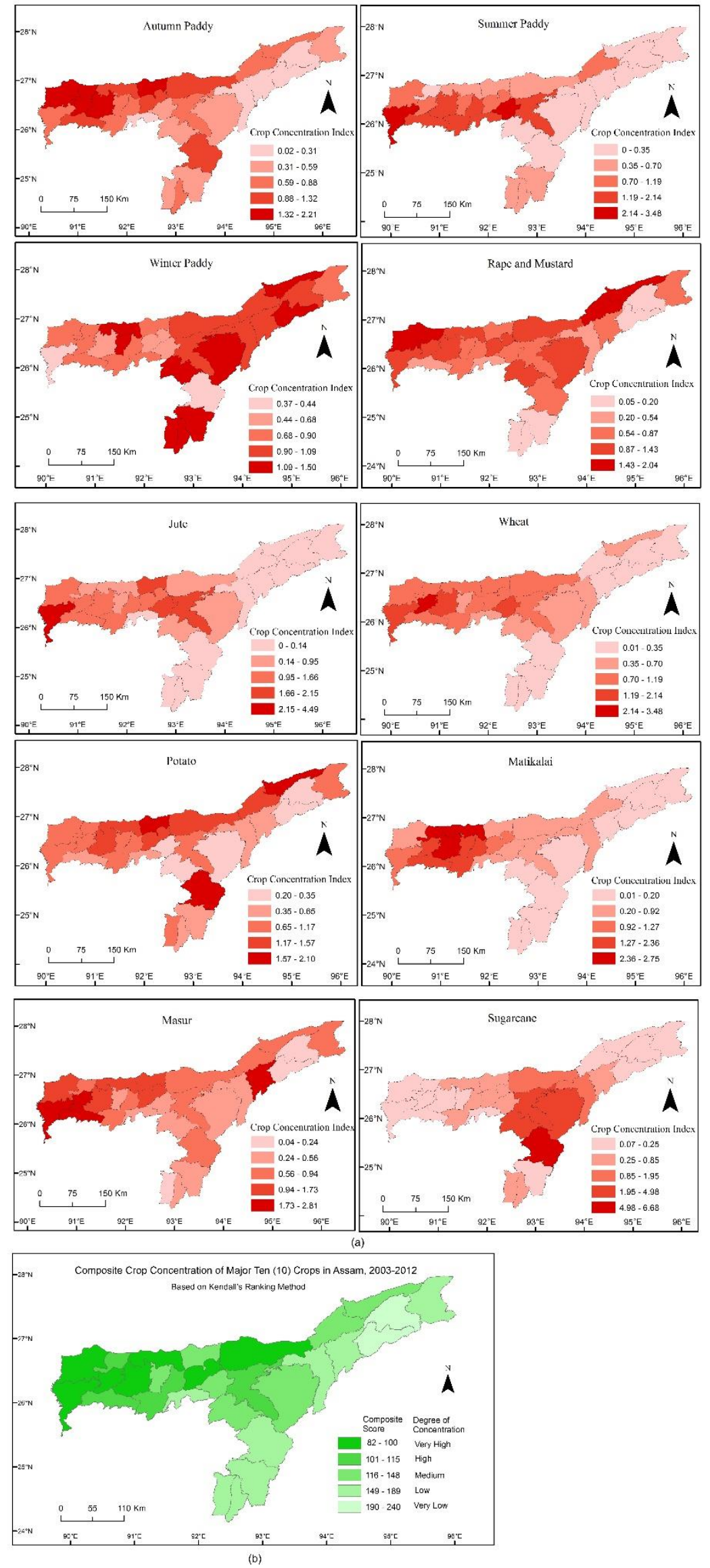

Figure 4 (a) District wise Crop Concentration of 10 major Crops based on Location Quotient Method in Assam, 2003-2012; (b) Composite Crop Concentration of 10 Major Crops based on Kendall's Ranking Method in Assam, 2003-2012. 


\section{Table 5 Correlation Amongst All Indices of Crop Diversification}

\begin{tabular}{|c|c|c|c|c|c|c|c|c|c|}
\hline Spearman's rho & $\mathrm{HI}$ & THI & Ol & GMI & JSM & GC & $\mathrm{HEI}$ & $\mathrm{EI}$ & CEI \\
\hline $\begin{array}{l}\text { Herfindahl Index } \\
\text { (HI) }\end{array}$ & 1 & $-.79 * *$ & $.85^{* *}$ & $-.79 * *$ & $.67 * *$ & $1 * *$ & $-.78 * *$ & $-.78 * *$ & $-.65 * *$ \\
\hline $\begin{array}{l}\text { Transformed HI } \\
\text { (THI) }\end{array}$ & $-.79 * *$ & 1 & $-.99 * *$ & $1 * *$ & $-.88 * *$ & $-.79 * *$ & $.98 * *$ & $.98 * *$ & $.86 * *$ \\
\hline Ogive Index (OI) & $.85^{* *}$ & $-.99 * *$ & 1 & $-.99 * *$ & $.87 * *$ & $.85 * *$ & $-.97 * *$ & $-.97 * *$ & $-.84 * *$ \\
\hline $\begin{array}{l}\text { Gibbs-Martin's } \\
\text { Index (GMI) }\end{array}$ & $-.79 * *$ & $1 * *$ & $-.99 * *$ & 1 & $-.88 * *$ & $-.79 * *$ & $.98 * *$ & $.98 * *$ & $.86 * *$ \\
\hline $\begin{array}{l}\text { Jasbir } \\
\text { Singh's(JSM) }\end{array}$ & $.67 * *$ & $-.88 * *$ & $.87 * *$ & $-.88 * *$ & 1 & $.68 * *$ & $-.92 * *$ & $-.92 * *$ & $-.83 * *$ \\
\hline $\begin{array}{l}\text { Gini's } \\
\text { Coefficient(GC) }\end{array}$ & $1 * *$ & $-.79 * *$ & $.85^{* *}$ & $-.79 * *$ & $.68 * *$ & 1 & $-.78 * *$ & $-.78 * *$ & $-.65 * *$ \\
\hline $\begin{array}{l}\text { Hart Entropy } \\
\text { Index (HEI) }\end{array}$ & $-.78 * *$ & $.98 * *$ & $-.97 * *$ & $.98 * *$ & $-.92 * *$ & $-.78 * *$ & 1 & $1 * *$ & $.86^{* *}$ \\
\hline Entropy Index (EI) & $-.78 * *$ & $.98 * *$ & $-.97 * *$ & $.98 * *$ & $-.92 * *$ & $-.78 * *$ & $1 * *$ & 1 & $.86 * *$ \\
\hline $\begin{array}{l}\text { Composite } \\
\text { Entropy Index } \\
\text { (CEI) }\end{array}$ & $-.65 * *$ & $.86 * *$ & $-.84 * *$ & $.85^{* *}$ & $-.83 * *$ & $-.65 * *$ & $.86 * *$ & $.86 * *$ & 1.0 \\
\hline \multicolumn{10}{|c|}{$\begin{array}{l}* * \text { Correlation was Significant at the } 0.01 \text { level (2-tailed) } \\
\text { Source: Authors }\end{array}$} \\
\hline
\end{tabular}



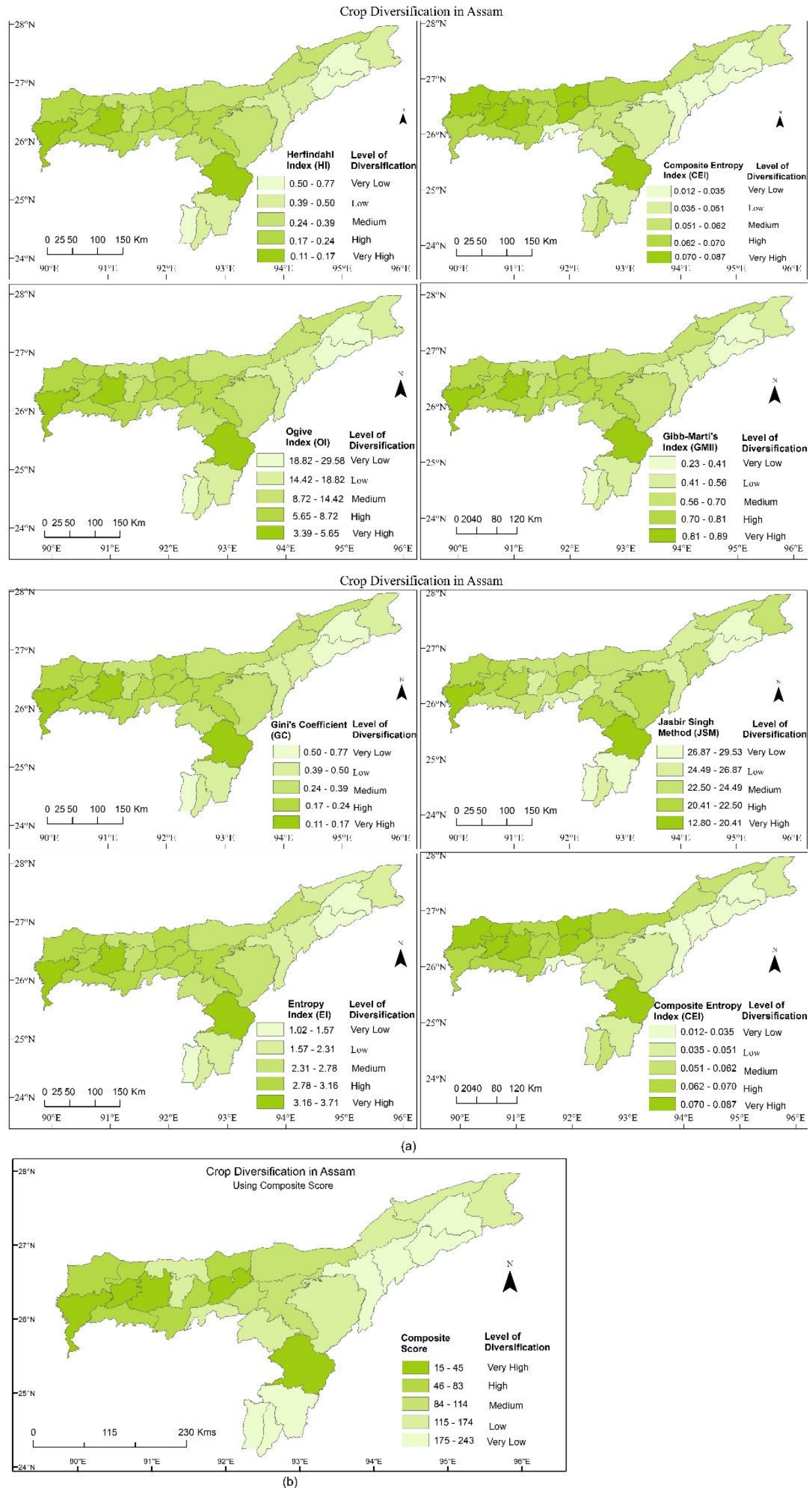

Figure 5 (a) Crop Diversification during 2003-2012 using Various Crop Indices in Assam. (b) Crop Diversification in Assam using Composite Score of all Indices derived from Kendall's Ranking Method during 2003-2012. 


\section{Conclusion}

In spite of an increasing trend of net sown area, production and gross cropped area, the spatial crop concentration and diversification were not uniform in Assam. The probable reasons underlying such non-uniform patterns in cropping pattern could be climate, soil type, access to institutional credit, flood-prone areas, water availability, use of HYV seeds and fertilisers (Mandal, 2014). Farmers in floodprone areas tended to adopt diversification of crops contrary to the practices in occasionally flooded and flood-free areas (Mandal, 2010; Mandal, 2014; Mandal et al., 2013). The districts with lowest levels of crop diversification, in eastern Assam and Barak valley, need to focus on diversification of crops in chronically floodaffected areas. Farms with diverse crops tend to generate more income than a single cropping pattern farm (Mandal, 2014). The variation in cropping pattern across the districts was quite significant and would seem to be indicative of either agricultural developmental activities not reaching the farmers or that policies and schemes were being not implemented successfully or that a lack of irrigation facilities and irregular rainfall were at fault. This analysis identified the areas of low crop diversification and concentration, as a precursor to taking measures to enhance the crop diversification in the region. The various methods used for assessing crop diversification revealed almost similar cropping patterns being derived from different indices. However, the entropy and ogive indices tended to provide better results.

\section{References}

Ahlawat, Vanita, \& Renu. (2016). Regional Disparity in Cropping Intensity and Relative Impact of Irrigation in Haryana. IOSR Journal of Business and Management, 18(09), 41-45.

Attaran, M., \& Zwick, M. (1987). Entropy and Other Measures of Industrial Diversification. Quarterly Journal of Business and Economics, 26,(4), 17-34.

Baruah, U. D. (2018). Crops and Farmers' Responses to Climate Change: A Case study of Assam. (unpublished doctoral dissertation), Gauhati University, Guwahati, India.

Bhatia, S. S. (1965). Patterns of crop concentration and diversification in India. Economic Geography, 41(1), 39-56.

Boserup, E. (1965). The Conditions of Agricultural Growth. Chicago, IL: Aldine Press.

Bradshaw, B., Dolan, H., \& Smit, B. (2004). Farmlevel adaptation to climatic variability and change: crop diversification in the Canadian prairies. Climate Change, 67(1), 119-141.

Caviglia, O.P., \& Andrade, F.H. (2010). Sustainable intensification of agriculture in the Argentinean Pampas: capture and use efficiency of environmental resources. American Journal of Plant Science Biotechnology, 3, 1-8.

Das, B., \& Mili, N. (2012). Pattern of Crop Diversification and Disparities in Agriculture: A Case Study of Dibrugarh District, Assam (India). Journal of Humanities And Social Science, 6(2), 3740.

De, U. K., \& Kamal, B. (2014). Crop Diversification in Assam and Use of Modern Inputs under Changing Climatic Condition. Journal of Climatology \& Weather Forecasting, 2(2), 1-14. doi: $10.4172 / 2332-2594.1000120$

De, U.K. (2003). Economics of Crop Diversification. New Delhi: Akansha Publishing House.

DES. (2015). State / district wise area, production, price and value of ten major crops in assam from 2003-04 to 2012-13. Beltola: Department of Economics and Statistics, Government of Assam, India.

Duncan, J. M. A., Saikia, S. D., Gupta, N., \& Biggs, E. M. (2016). Observing climate impacts on tea yield in Assam, India. Applied Geography, 77, 64-71. doi: 10.1016/j.apgeog.2016.10.004 
FAO (2001). Crop diversification in the AsiaPacific region.RAP Publication 2001/03. Food and Agriculture Organization, Bangkok.

Gebreyesus, Baharu. (2016). Determinants of Livelihood Diversification: The Case of Kembata Tambaro Zone, Southern Ethiopia. Journal of Poverty, Investment and Development, 23, 1-10.

Gibbs, J., \& Martin, W. (1962). Index of Diversification. In R. Hammond \& P.S. McGullagh (Eds.), Quantitative Techniques in Geography: An Introduction (pp. 386). Oxford: Clarendon Press.

Guha, A. (1966). Ahom Migration: Its Impact on Rice Economy of Medieval Assam. Artha Vijayana, 9(2,), 135-136.

Hart, P. E. (1971). Entropy and other measures of concentration. Journal of the Royal Statistical Society, Series A (General), 134(1), 73-85.

Hazra, C.R. (2001). Crop diversification in India. In M.K. Papademetriou \& F.J. Dent (Eds.), Crop diversification in the Asia-Pacific region (pp. 32-50). Bangkok, Thailand: FAO Regional Office for Asia and the Pacific.

Hussain, M. . (2001). Syatematic Agricultural Geogrpahy. New Delhi: Rawat Publications.

Jain, R., Raju, S.S. , Immanuelraj, K., Srivastava, S.K., Kaur, A.P., \& Singh, J. (2015). Manual on Methodological Approach for Developing Regional Crop Plan. New Delhi: ICAR - National Institute of Agricultural Economics and Policy Research.

Jones, W. D. (1930). Ratio and Isopleth Maps in Regional Investigation of Agricultural Land Occupance. Annals of the Association of American Geographers, 20, 177-195.

Kendall, M. G. (1939). The Geographical Distribution of Crop Productivity in
England. Journal of the Royal Statistical Society, 102(1), 21-62.

Mandal, R. (2010). Cropping Patterns and Risk Management in the Flood Plains of Assam. Economic and Political Weekly, 45(33), 78-81.

Mandal, R. (2014). Flood, cropping pattern choice and returns in agriculture: A study of Assam plains, India. Economic Analysis and Policy, 44(3), 333-344. doi: 10.1016/j.eap.2014.08.001

Mandal, R., \& Bezbaruah, M. P. (2013). Diversification of Cropping Pattern: Its Determinants and Role in Flood Affected Agriculture of Assam Plains. Indian Journal of Agricultural Economy, 68, 169181.

Mengxiao, Z. (2001). Crop diversification in China. In M.K. Papadimitriou \& F.J. Dent (Eds.), Crop Diversification in the AsiaPacific Region (pp. 24-31). Bangkok, Thailand: FAO Regional Office for Asia and the Pacific.

Novelli, Leonardo E., Caviglia, Octavio P., \& Piñeiro, Gervasio. (2017). Increased cropping intensity improves crop residue inputs to the soil and aggregateassociated soil organic carbon stocks. Soil and Tillage Research, 165, 128-136. doi: 10.1016/j.still.2016.08.008

Pal, S., \& Kar, S. (2012). Implications of the methods of agricultural diversification in reference with Malda district: Drawback and rationale. International Journal of Food, Agriculture and Veterinary Sciences, 20(2), 97-105.

Palan, N. (2010). Measurement of Specialization -The Choice of Indices. FIW - Working Paper, 62.

Raju, A. (2012). Patterns of Crop Concentration and Diversification in Vizianagaram District of Andhra Pradesh. Transactions of the Institute of Indian Geographers, 34(2).

Ranjana. (2012). Trends in crop diversification in Punjab-Haryana plains: $1965-66$ to 2005- 
06. (unpublished doctoral dissertation), Punjabi University, Patiala, India.

Roy, P. B., \& Barman, U.K. (2014). Crop Concentration and Diversification in Jalpaiguri District Of West Bengal: A Case Study. International Journal of Food, Agriculture and Veterinary Sciences, 4(3).

Samen, S. (2010). A primer on export diversification: key concepts, theoretical underpinnings and empirical evidence (pp. 1-23): Growth and Crisis Unit World Bank Institute.

Saraswat, S.P., \& Sharma, H. (2014). Dynamics of Diversification in Hill Agriculture - A case study of Village Kot, Hamirpur, Himachal Pradesh. In B. Gangaiah, B.S. Bhandari, Sukh Pal Singh, Pramod Kumar, Chandrasekhar Rao \& Narain Singh (Eds.), Agricultural Situation in India (Vol. LXX). New Delhi: Directorate of Economics and Statistics, Department of Agriculture and Co-Operation, Ministry of Agriculture, Government of India.

Scherer, F.M. (1980). Industrial market structure and economic performance (Second Edition ed.). Boston: Hougton Mifflin Company.

Schuh, E., \& Barghouti, S. (1988). Agricultural diversification in Asia. Finance and Development, 25, 41-44.

Sharma, K.R. (2008). Measuring Economic Diversification in Hawaii: Research and Economic Analysis Division (READ), Department of Business, Economic Development and Tourism of Hawaii.
Singh, J. (1976). Agricultural Geography. New Delhi: Tata McGraw Hill Publishing Co. Ltd.

Sinha, K. (2001). Evaluation of agricultural policies of Assam a politico geographical basis for economic liberalisation. (unpublished doctoral dissertation), North-Eastern Hill University, Shillong, India.

Smith, H.L. (1949). Agricultural Land Use in lowa. Economic Geography, 25, 190-200.

Tabner, I. (2007). A Review of Concentration, Diversity or Entropy Metrics in Economics, Finance, Ecology and Communication Science. The International Journal of Interdisciplinary Social Sciences, 2(4), 53-60.

Tauer, L.W. (1992). Diversification of production activities across individual states. Journal of Production Agriculture, 5, 210-214.

Tress, R. C. (1938). Unemployment and Diversification of Industry. The Manchester School, 9(2), 140-152.

Wasylenko, J.M., \& Erickson, R.A. (1978). On Measuring Economic Diversification. Land Economics, 54(1), 106-109.

Weaver, J.C. (1954a). Changing Patterns of Cropland Use in the Middle West. Economic Geography, 30, 1-47.

Weaver, J.C. (1954b). Crop Combination in Middle West. Geographical Review, 44, 175-200. 